\title{
Structural and morphogenical characteristics of black oats and Italian ryegrass on pasture submitted to two grazing intensities
}

\author{
Anna Carolina Cerato Confortin ${ }^{1}$, Marta Gomes da Rocha ${ }^{1}$, Fernando Luiz Ferreira de \\ Quadros $^{1}$, Carine Lisete Glienke ${ }^{1}$, Guilherme Ebling Rossi ${ }^{1}$, Andréia Barros de Moraes ${ }^{1}$ \\ 1 Universidade Federal de Santa Maria - UFSM/RS.
}

ABSTRACT - Morphogenical and structural characteristics of black oats (Avena strigosa Schreb.) and Italian ryegrass (Lolium multiflorum Lam.) on pastures managed under two grazing intensities were quantified by using marked tiller technique. The expected intensities of disappearance of forage mass initial value were 35\% (low) and 65\% (high). Experimental animals were sheep and interval among grazing was determined through 300 degree-day thermal sum. The experimental design was completely randomized with two grazing intensities and two replicates. Leaf blades of oats and ryegrass were removed at an average proportion of $57.5 \%$ of their initial length for both grazing intensities. Among the morphogenical characteristics of oats, only elongation rate of defoliate leaf differed between grazing intensities, with values of 0.059 and $0.081 \mathrm{~cm} /$ degree-day for low and high intensities, respectively. Grazing intensities did not alter structural characteristics of oats mixed with ryegrass and red clover. High grazing intensity enables maintenance of a higher number of ryegrass expanding leaves (1.7 leaves/tiller), thus it is suggested for management of pastures with oats mixed with Italian ryegrass and red-clover on intermittent grazing.

Key Words: intermittent grazing, leaf lifespan, marked tillers, sheep, Trifolium pratense L.

\section{Características estruturais e morfogênicas de aveia-preta e azevém-anual em pastagem submetida a duas intensidades de pastejo}

RESUMO - As características morfogênicas e estruturais de aveia-preta (Avena strigosa Schreb.) e azevém (Lolium multiflorum Lam.), em pastagem manejada sob duas intensidades de pastejo, foram quantificadas por meio da técnica de perfilhos marcados. As intensidades pretendidas de desaparecimento do valor da massa de forragem inicial foram $35 \%$ (baixa) e 65\% (alta). Os animais experimentais foram ovinos e o intervalo entre pastejos foi determinado pela soma térmica de 300 graus-dia. O delineamento experimental foi inteiramente casualizado com duas intensidades de pastejo e duas repetições. As lâminas foliares de aveia e azevém foram removidas na proporção média de 57,5\% do seu comprimento inicial em ambas as intensidades de pastejo. Entre as características morfogênicas da aveia, apenas a taxa de elongação de lâmina desfolhada diferiu entre as intensidades de pastejo, com valores de 0,059 e 0,081 cm/graus-dia para as intensidades alta e baixa, respectivamente. As intensidades de pastejo não provocaram alterações nas características estruturais da aveia em consorciação com azevém e trevo-vermelho. A intensidade de pastejo alta possibilita a manutenção de maior número de folhas em expansão de azevém (1,7 folhas/perfilho), portanto é recomendável para o manejo de pastagens da aveia em consórcio com azevém e trevo-vermelho sob pastejo intermitente.

Palavras-chave: duração de vida das folhas, ovinos, pastejos intermitentes, perfilhos marcados, Trifolium pratense L.

\section{Introduction}

Several changes have occurred in the food international scenario and, among them, the concern from governments and consumers regarding to consumption of healthy food is growing (Sarto et al., 2003). In this scenario, it stands out the benefits of consuming pasture-raised animal products (Nuernberg et al., 2005).
Among winter forage species cultivated in Rio Grande do Sul, black oats (Avena strigosa Schreb.) and Italian ryegrass (Lolium multiflorum Lam.) cv. Comum, which are often utilized mixed with clovers such as red clover (Trifolium pratense L.) are highlighted. To reach the potential use of this resource, maximizing stability and forage production throughout pasture growing season, investigating the factors that interfere with their growth is essential. 
The process of defoliation influences forage plants development and, according to Lemaire (2001), the response by grasses to that process depends on the proportion of removed tissue, the degree of defoliation of neighboring plants and on the photosynthetic capacity of remaining leaves.

The influence of defoliation on the growth of Italian ryegrass has been studied in recent years (Glienke et al., 2010). Pontes et al. (2003) observed higher values of elongation rate and leaf blade final size as the canopy height was increased. Cauduro et al. (2006) also found higher rates of elongation of Italian ryegrass when it was managed under low grazing intensity. However, information regarding the effects of grazing intensity on growth of Italian ryegrass in mixture with black oats is still insufficient and needed, given the relevance of intercropping systems on livestock production in southern Brazil.

From the knowledge on the morphogenic responses from black oats and Italian ryegrass to different grazing intensities, it may be possible to set a management strategy that enables high animal performance without compromising plant growth. So, this study was conducted to evaluate the influence of different grazing intensities on growth and structure of these grasses when mixed with red clover.

\section{Material and Methods}

The experiment was carried out at Universidade Federal de Santa Maria (UFSM) from May to September 2006, totaling 132 days. The experimental design was completely randomized, with two grazing intensities and two area replications. The grazing intensities were: low, with $35 \%$ of the initial forage mass (IFM) dry matter (DM) disappearance; and high, with $65 \%$ of IFM DM disappearance.

The experimental area was located in the physiographic region of Depressão Central of Rio Grande do Sul on a soil classified as Paleudalf (Embrapa, 2006). The region is characterized with humid subtropical climate (Cfa), according to the Köppen classification. Soil samples collected from 0-10 cm depth showed the following chemical characteristics: pH- $\mathrm{H}_{2} \mathrm{O}: 5.4$; \% clay: $19 \mathrm{~m} / \mathrm{V} ; \mathrm{K}: 40 \mathrm{mg} / \mathrm{L} ; \%$ OM: $2.2 \mathrm{~m} / \mathrm{V}$; Al: $0.0 \mathrm{cmol} / \mathrm{L} ; \mathrm{Ca}: 6.4 \mathrm{cmol} / \mathrm{L} ; \mathrm{P}: 6 \mathrm{mg} / \mathrm{dm}^{3} ; \mathrm{Mg}: 2.7 \mathrm{cmol} / \mathrm{L}$; CEC pH 7: 16.1 .

Weather conditions data for the experimental period were obtained from the UFSM meteorological station (Figure 1).

The experimental area was 0.4 ha, subdivided in four 0.1- ha paddocks. The sowing of oats (Avena strigosa Schreb.) and Italian ryegrass (Lolium multiflorum Lam) cv. Comum was performed on May $18^{\text {th }}, 2006$, with minimum soil tillage, using a mechanical broadcast seeder. It was
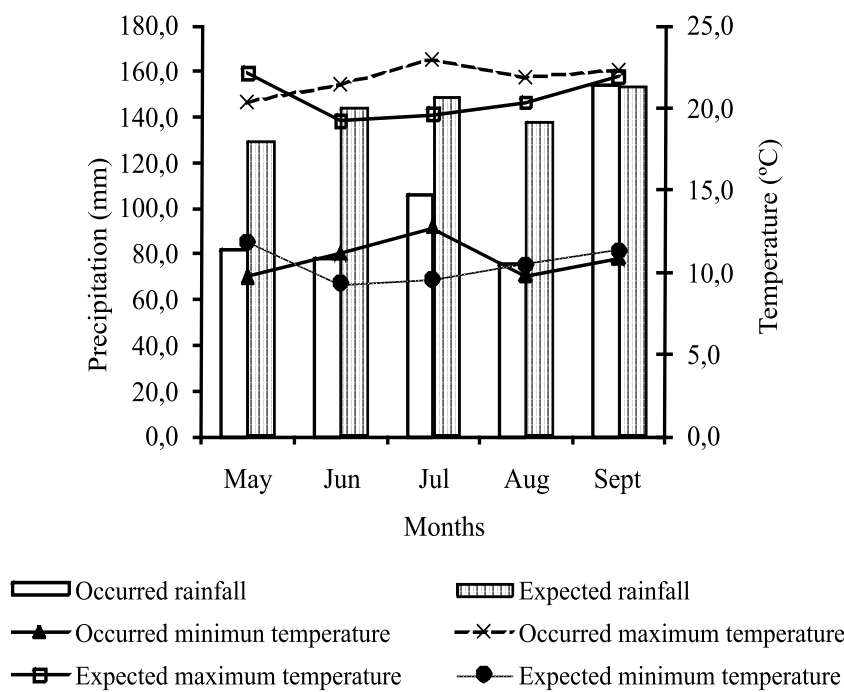

Figure 1- Rainfall and maximal and minimal occurred and expected temperature during the experimental period.

applied $250 \mathrm{~kg} / \mathrm{ha}$ of 5-20-20 (NPK) formula at seeding. Red clover (Trifolium pratense L.) cv. LE 116 was established on May $21^{\text {st }}$ through manual seeding, after inoculation with specific inoculants and seed pelleting. Sowing densities were 60,30 and $10 \mathrm{~kg} /$ ha for oats, Italian ryegrass, and red clover, respectively. It was applied $22.5 \mathrm{~kg} / \mathrm{ha}$ of nitrogen $(\mathrm{N}), 45$ days after sowing and after each grazing cycle, totaling $90 \mathrm{~kg} / \mathrm{ha}$ of $\mathrm{N}$.

The grazing method was intermittent and the animals were crossbred Texel $\times$ Ile de France hoggets, approximately at eight months of age and weight at $26.2 \pm 3.3 \mathrm{~kg}$ in July 2006. These hoggets had free access to water and mineral salt.

Entrance of animals on pasture for the first grazing period occurred when forage mass (FM) was between 1,500-2,000 kg/ha DM. For the other grazing cycles, the interval between grazings was determined by the accumulated thermal sum of 300 degree-days, which is the value required for appearance of two expanded leaves of Italian ryegrass (Quadros \& Bandinelli, 2005).

The accumulated thermal sum (TT) was calculated based on the equation: $\mathrm{TT}=\Sigma\left(\mathrm{DAT}-5^{\circ} \mathrm{C}\right)$, in which, $\mathrm{DAT}=$ the daily average temperature of the period and $5^{\circ} \mathrm{C}$ $=$ the value considered as the growth base temperature of winter species (Cooper \& Tainton, 1968). The average daily temperature was calculated according to INMET (2004): $\mathrm{DAT}=\mathrm{MxT}^{\circ}+\mathrm{MnT}^{\circ}+\mathrm{T}^{\circ} 9 \mathrm{am}+\left(2 \times \mathrm{T}^{\circ} 9 \mathrm{pm}\right) / 5$, where: $\mathrm{Mx}$ $\mathrm{T}^{\circ}=$ maximal daily temperature $\left({ }^{\circ} \mathrm{C}\right), \mathrm{MnT}^{\circ}=$ minimal daily temperature $\left({ }^{\circ} \mathrm{C}\right), \mathrm{T}^{\circ} 9$ a.m. $=$ temperature at 9 am and $\mathrm{T}^{\circ} 9$ p.m. $=$ the temperature at 9 p.m. 
Grazing cycles occurred from July $19^{\text {th }}$ to $22^{\text {nd }}$; from August $23^{\text {th }}$ to $29^{\text {th }}$ and from September $28^{\text {th }}$ to October $1^{\text {st }}$, 2006. The morphogenetic and structural characteristics of grasses were evaluated every three or four days, during the periods between two successive grazings, called the evaluation period (from July $22^{\text {nd }}$ to September $27^{\text {th }}$, 2006). The morphogenetic and structural characteristics of oats were evaluated only in the first evaluation period (July $22^{\text {nd }}$ to August $22^{\text {nd }}$, 2006).

The stocking density, kg/ha of body weight (BW), was calculated for each grazing intensity, adopting the value of $4.5 \%$ of LW as the disappearance rate of dry matter (Heringer \& Carvalho, 2002). On the day before the beginning of grazings, the animals were weighed after 12 hours fasting and identified according to their participation on each grazing intensity.

Forage mass (FM) was determined by five cuts close to the ground, before and after each grazing, using as reference a $0.0625-\mathrm{m}^{2}$ square. Based on these samples of the cuts, the DM content of pasture was determined. Its botanical and morphological composition was estimated by manual separation of the components: oats and Italian ryegrass leaves (leaf blades), oats and Italian ryegrass stem (sheath leaf + stem), clover (leaflets + petioles), dead material and other species. All samples were weighed and dried in a forced air circulation oven at $55^{\circ} \mathrm{C}$ for 72 hours, and from this weight, dry matter production was calculated, in $\mathrm{kg} / \mathrm{ha}$, from each botanical and morphological component.

The rate of forage accumulation ( $\mathrm{kg} / \mathrm{ha} / \mathrm{day})$ was obtained by subtracting the value of the forage mass before starting a new period of occupation by the value of forage mass at the end of the previous occupation divided by the number of days elapsed between the two periods.

The sward height $(\mathrm{cm})$ was measured before and after each grazing by walking across a paddock through 20 random points with a centimeter-graduaded ruler, measuring the distance from the ground to the average height of the curvature of grass leaves.

The forage disappearance was calculated according to the equation: $\mathrm{FD}=100-((\mathrm{FME} \times 100) /(\mathrm{FMS}+\mathrm{TAD}))$, where $\mathrm{FD}=$ disappearance rate of forage after grazing; $\mathrm{FME}=$ value of forage mass at the end of grazing $(\mathrm{kg} / \mathrm{ha}$ $\mathrm{DM}$ ); FMS = value of forage mass at the start of grazing $(\mathrm{kg} / \mathrm{ha} \mathrm{DM})$ and TAD $=$ TAF multiplied by the number of days in the occupation period.

To evaluate the morphogenetic and structural variables, it was used the technique of "marked tillers" (Carrère et al., 1997). In each paddock, 40 tillers (20 of oats plus 20 of Italian ryegrass) were located in four transects and marked with colored soft plastic rings. Transects were located at 9-m intervals and tillers at five meters between them in the transects.

The evaluations were performed every 3-4 day intervals throughout the experiment. The sheath height and the length of fully expanded (with visible ligule) or expanding leaf blades were measured in centimeters. It was also observed the condition of the leaves: senescent or not, intact or defoliated. The fully expanded leaves were measured from the ligule, while the expanding leaves were measured from the ligule of the last expanded leaf. Only the green portion of the leaf blade was measured in the senescent leaves. Sheath height was measured from the soil until the ligule of the last mature leaf.

The originated variables were: the final length of intact and defoliated leaf blades, number of expanded leaves and total number of green leaves. Phyllochron was considered as the inverse value of the slope of the linear regression between the number of leaves per tiller and the thermal sum of the corresponding period (Pontes et al., 2003). Leaf lifespan was calculated through the product of the phyllochron of the period and the average number of green leaves per tiller. The duration of the elongation was obtained through the products of phyllochron and the average number of leaves in expansion per tiller.

The rates of elongation and senescence of intact and defoliated leaves, in cm/degree-days, were calculated by the ratio between the elongation or average senescence of leaves per tiller between two consecutive assessments and the thermal sum in the same period. It was also evaluated the intensity of defoliation (\% ID) through the equation: \% ID = ((LLBb-LLBe $) / L L B b) \times 100$, where LLBb and LLBe, respectively, are the length of the leaf blade at the beginning and at the end of grazing.

Tiller density (tiller $/ \mathrm{m}^{2}$ ) was assessed after each grazing in four fixed locations in each paddock, with an area of $0.0625 \mathrm{~m}^{2}$ each, where live tillers of oats and Italian ryegrass were counted. These values were extrapolated for tillers $/ \mathrm{m}^{2}$. The mass of tillers (g/tiller) was evaluated in areas similar to those used in the evaluation of tiller density, in which all living tillers of oats and Italian ryegrass were cut and weighed.

Data were subjected to analysis of variance and $\mathrm{F}$ test at $10 \%$ level of significance, using GLM (General Linear Model). Correlation test was performed and polynomial regression considering the $5 \%$ level of significance. In order to identify the independent variables that influence on morphogenetic variables of oats and Italian ryegrass, it was used the stepwise procedure, ignoring variables with 
determination coefficients $\left(\mathrm{R}^{2}\right)$ lower than 0.50 . Data were analyzed using Statistical Analysis System software, version 8.2 (2001).

\section{Results and Discussion}

Participation of red clover in the forage mass at the beginning of the grazing periods was on average 1.5 and $0.7 \%$ in the first and second periods of pasture utilization, respectively. Mixtures of clover and grasses in pastures can improve the availability of nitrogen to the system through its recycling and transference from the clover to the grass companion (Pedreira et al., 2001) but due to the low participation by clover on the pasture, only morphogenesis of grasses was evaluated.

There was no interaction between grazing intensity and evaluation cycle for the following variables: total forage mass and mass of botanical and morphological components ( $\mathrm{kg} / \mathrm{ha} \mathrm{DM})$, canopy height $(\mathrm{cm})$ and leaf blade/stem ratio at entrance and exit of animals from the pasture and percentage of leaf blade disappearance (D\%) of oats + Italian ryegrass + red clover pasture $(\mathrm{P}>0.1$; Table 1$)$. The observed forage disappearances were 37.9 and $61.4 \%$ of the initial forage mass value for low and high defoliation intensities, respectively.
Total forage mass was similar between the two intensities $(\mathrm{P}=0.121$; Table 1$)$ at the end of grazing periods when the animals left the paddocks and this variable seems to be not appropriate to describe the grazing intensities since the DM content of forage depends on its structural components. So, leaf blade residual mass $(\mathrm{P}=0.037)$ and leaf blade percentage of disappearance $(\mathrm{P}=0.055)$ are more suitable to describe the effect of grazing intensity on the pasture structure (Table 1). Leaf blade is the structural component preferentially selected by grazing herbivores and primarily responsible for the canopy light interception.

Leaf blade residual mass (oats + Italian ryegrass + red clover) was greater at low intensity $(\mathrm{P}=0.037)$ and this greater value may be responsible for a higher initial growth of the canopy, since the speed of plant regrowth after grazing depends mainly on the remaining leaf area (Lemaire \& Chapman, 1996).

Leaf blade average disappearance values of oats and Italian ryegrass in the first grazing cycle were 35.9 and 91.4\% respectively. The main purpose of using black oats mixed with Italian ryegrass is to anticipate the utilization of pasture (Quadros \& Maraschin, 1987). In this experiment, the potential of black oats for precocity has not been explored since the first occupation of the pasture occurred only on July $19^{\text {th }}, 2006$ and probably, on the first grazing,

Table 1 - Forage mass and botanical and morphological compounds of oats + Italian ryegrass + red clover

\begin{tabular}{|c|c|c|c|c|c|c|c|}
\hline \multirow[t]{3}{*}{ Variable } & \multicolumn{2}{|c|}{ Occupation period 1} & \multicolumn{2}{|c|}{ Dccupation period 2} & \multicolumn{2}{|c|}{ Probability } & \multirow{3}{*}{$\begin{array}{l}\text { Coefficient of } \\
\text { variation, \% }\end{array}$} \\
\hline & \multicolumn{4}{|c|}{ Grazing intensities } & \multirow{2}{*}{$\begin{array}{l}\text { Grazing } \\
\text { intensities }\end{array}$} & \multirow{2}{*}{$\begin{array}{l}\text { Occupation } \\
\text { period }\end{array}$} & \\
\hline & Low & High & Low & High & & & \\
\hline & \multicolumn{7}{|c|}{ Oats + Italian ryegrass + Red clover } \\
\hline Entrance forage mass, $\mathrm{kg}$ of $\mathrm{DM} / \mathrm{ha}$ & $1,819.5$ & $1,501.0$ & $3,568.0$ & 2.884 .6 & 0.359 & 0.008 & 8.2 \\
\hline Exit forage mass, kg of DM/ha & $1,541.3$ & 730.7 & $1,881.6$ & 1.088 .0 & 0.121 & 0.252 & 23.6 \\
\hline Entrance leaf blade mass, $\mathrm{kg}$ of $\mathrm{DM} / \mathrm{ha}$ & $1,596.2$ & $1,371.1$ & $1,368.7$ & 1.509 .4 & 0.655 & 0.638 & 7.9 \\
\hline Exit leaf blade mass, kg of DM/ha & 690.9 & 177.2 & 338.9 & 290.8 & 0.037 & 0.538 & 58.9 \\
\hline Entrance stem mass, $\mathrm{kg}$ of $\mathrm{DM} / \mathrm{ha}$ & 160.5 & 65.6 & $1,643.3$ & 997.9 & 0.078 & 0.008 & 20.7 \\
\hline Exit stem mass, kg of DM/ha & 690.3 & 391.3 & $1,049.7$ & 502.2 & 0.089 & 0.164 & 23.4 \\
\hline Entrance leaf/stem & 13.9 & 21.0 & 0.8 & 1.6 & 0.241 & 0.015 & 57.3 \\
\hline Exit leaf/stem & 1.0 & 0.4 & 0.3 & 0.5 & 0.166 & 0.388 & 49.8 \\
\hline Disappearance of leaf blades, \% & 57.8 & 87.5 & 75.2 & 80.5 & 0.055 & 0.625 & 17.3 \\
\hline Entrance canopy high, cm & 24.0 & 21.2 & 38.0 & 39.2 & 0.277 & 0.053 & 17.7 \\
\hline \multirow[t]{2}{*}{ Exit canopy high, cm } & 16.2 & 12.0 & 11.6 & 14.0 & 0.260 & 0.156 & 6.2 \\
\hline & \multicolumn{7}{|c|}{ Oats } \\
\hline Entrance leaf blade mass, kg of DM/ha & 760.6 & 328.0 & 725.3 & 617.7 & 0.412 & 0.610 & 49.5 \\
\hline Exit leaf blade mass, kg of DM/ha & 614.4 & 83.1 & 90.0 & 56.4 & 0.098 & 0.237 & 65.4 \\
\hline Disappearance of leaf blades, \% & 19.2 & 74.0 & 87.6 & 90.6 & 0.054 & 0.081 & 28.8 \\
\hline Entrance stem mass, $\mathrm{kg}$ of $\mathrm{DM} / \mathrm{ha}$ & 115.2 & 32.8 & 1.381 .3 & 728.3 & 0.003 & 0.013 & 28.1 \\
\hline \multirow[t]{2}{*}{ Exit stem mass, kg of DM/ha } & 467.1 & 230.1 & 755.4 & 294.4 & 0.204 & 0.198 & 30.0 \\
\hline & \multicolumn{7}{|c|}{ Italian ryegrass } \\
\hline Entrance leaf blade mass, kg of DM/ha & 835.6 & 1043.1 & 643.4 & 891.6 & 0.204 & 0.385 & 25.8 \\
\hline Leaf blade mass of end, kg of DM/ha & 66.5 & 94.0 & 248.9 & 234.4 & 0.948 & 0.194 & 73.5 \\
\hline Disappearance of leaf blades, \% & 92.0 & 91.2 & 61.2 & 73.8 & 0.641 & 0.115 & 15.9 \\
\hline Entrance stem mass, $\mathrm{kg}$ of $\mathrm{DM} / \mathrm{ha}$ & 45.3 & 32.8 & 262.0 & 249.6 & 0.628 & 0.003 & 24.4 \\
\hline Stem mass of end, $\mathrm{kg}$ of DM/ha & 223.2 & 161.2 & 294.3 & 207.6 & 0.414 & 0.104 & 13.1 \\
\hline
\end{tabular}


the lowest average disappearance of oats leaf blade have been caused by more advanced developmental stage of this species compared to Italian ryegrass.

Stem mass of oats and Italian ryegrass were greater at the entrance of animals in the second period of pasture occupation (Table 1). This increase in stem proportion over the grass cycle is due to internodes lengthening at the beginning of the reproductive stage (Langer, 1979). Rocha et al. (2007) also observed similar behavior in different cultivars of winter forage species evaluated under cuts. The greater sward height observed at entry of animals at the second period of pasture occupation is also related to the cycle phase and to the elongation of internodes of oats and ryegrass.

The increase in stem mass resulted in lower leaf blade/ stem ratio in the second period of pasture occupation ( $P=0.015)$, indicating that at the first grazing, animals had better conditions for selecting leaves since leaf blade/stem ratio directly affects the ability of the herbivore to select the forage of their preference. Besides its importance in animal performance, this variable is related to the adaptability by the grass for grazing purposes (Pinto et al., 1994). According to these authors, a high leaf blade/stem ratio provides grasses a better grazing adaptation, as it represents a moment of phenological development in which the apical meristems are close to the ground and therefore less vulnerable to destruction.

There was no grazing intensity $\times$ evaluation period interaction for canopy height, sheath height, length of intact and defoliated leaf blade, defoliation intensity, number of expanded and expanding green leaves, population density and tiller mass of Italian ryegrass $(\mathrm{P}>0.1)$. Grazing intensity did not affect the density and tiller mass of oats and Italian ryegrass ( $\mathrm{P}>0.1$; Table 2). Bandinelli (2004) evaluated two leaf blade biomasses on oats + ryegrass pasture and observed similar values for oats tiller density and higher values for Italian ryegrass tiller density. The lower tiller density observed in this experiment can be attributed to the grazing method with intermittent stocking because the potential rate of appearance of tillers can be achieved only for low leaf area index of the sward (Simon \& Lemaire, 1987).

Sheath height, which is the physical barrier for grass apprehension by herbivores, did not differ among grazing intensities $(\mathrm{P}>0.1)$. The sheath height of the oats, in mixtures limits the grazing depth due to its greater value in relation to sheath height of Italian ryegrass (Table 2).

The positive relationship between sheath height and blade length of intact leaf (Difante, 2003) was not observed in this trial because the highest blade length of intact leaf in Italian ryegrass occurred in the first evaluation period when the sheath height was lower (Table 2). This could be related to the fact that leaf blade length is determined by the relationship between the duration of elongation (higher in grasses with greater sheath height) and leaf elongation rate (cm/degree-days). In this study, the duration of elongation affected negatively the elongation rate of intact leaves of Italian ryegrass, so when the sheath height was higher there was a reduction in the elongation rate of intact leaves and, consequently, in the blade length of intact leaf.

The tested grazing intensities had no influence on defoliation intensities (\%) of oats and Italian ryegrass (Table 2). Values near $50 \%$ for this variable were also observed by Lemaire \& Mazzanti (1994). These authors stated that the proportion of blade length in removed leaf is relatively constant at each defoliation.

The defoliation intensity (\%) of Italian ryegrass is positively correlated with canopy height $(\mathrm{r}=0.71 ; \mathrm{P}=0.05)$ when mixed with oats and red clover. On the other hand, in exclusive Italian ryegrass pasture, Pontes et al. (2004) observed a $1.48 \%$ reduction in the defoliation intensity of

Table 2 - Structural characteristics of oats and Italian ryegrass and coefficients of variation (CV, \%), according with grazing intensities and evaluation periods

\begin{tabular}{|c|c|c|c|c|c|c|c|c|}
\hline \multirow[t]{3}{*}{ Variable } & \multicolumn{2}{|c|}{ Oats } & \multirow{3}{*}{$\mathrm{CV}, \%$} & \multicolumn{4}{|c|}{ Italian ryegrass } & \multirow{3}{*}{$\mathrm{CV}, \%$} \\
\hline & \multicolumn{2}{|c|}{$\begin{array}{c}\text { Period } 1 \\
(7 / 22 / 2006 \text { to } 8 / 22 / 2006)\end{array}$} & & \multicolumn{2}{|c|}{$\begin{array}{c}\text { Period } 1 \\
(7 / 22 / 2006 \text { to } 8 / 22 / 2006)\end{array}$} & \multicolumn{2}{|c|}{$\begin{array}{c}\text { Period } 2 \\
(8 / 29 / 2006 \text { to } 9 / 27 / 2006)\end{array}$} & \\
\hline & Low & High & & Low & High & Low & High & \\
\hline Canopy high, cm & 26.3 & 26.7 & 0.2 & 26.3 & 26.7 & 30.6 & 25.7 & 4.8 \\
\hline Pseudostem high, cm & 19.1 & 12.4 & 13.6 & $4.3^{1}$ & $3.9^{1}$ & $5.9^{1}$ & $5.8^{1}$ & 8.3 \\
\hline Length of intact leaf blades, cm & 17.1 & 17.2 & 6.7 & $16.0^{1}$ & $12.8^{1}$ & $10.8^{1}$ & $9.4^{1}$ & 12.2 \\
\hline Length of defoliated leaf blades, cm & 7.9 & 7.9 & 15.2 & 7.3 & 7.3 & 4.7 & 5.2 & 22.9 \\
\hline Defoliation intensity, \% & 58.3 & 55.7 & 14.2 & 69.8 & 44.5 & 73.2 & 45.0 & 9.0 \\
\hline Green leaves, number & 1.9 & 2.0 & 1.3 & 3.2 & 3.3 & 2.9 & 3.1 & 4.6 \\
\hline Leaves in expansion, number & 1.0 & 1.0 & 1.9 & $1.6^{2}$ & $1.7^{2}$ & $1.5^{2}$ & $1.7^{2}$ & 1.9 \\
\hline Tiller density, tillers $/ \mathrm{m}^{2}$ & 428.0 & 486.0 & 15.3 & 1.558 & 1.758 & 1.318 & 1.948 & 37.2 \\
\hline Tillers mass, g/tillers & 0.15 & 0.07 & 0.5 & 0.04 & 0.03 & 0.03 & 0.02 & 36.0 \\
\hline
\end{tabular}

1 and 2 Differ $(\mathrm{P}<0.1)$ among evaluation periods and grazing intensities, respectively. 
ryegrass for each centimeter added in the canopy height. This difference may be due to the fact that, in mixtures, the canopy height does not correspond to the height of Italian ryegrass but to height of oats.

The intensity of defoliation was similar for Italian ryegrass and oats, with an average of $57.5 \%(\mathrm{P}=0.77)$. Thus, the greater leaf blade disappearance of Italian ryegrass in relation to oats, in the first grazing cycle, may be linked to an increased frequency of ryegrass defoliation. At the animals entrance in the first grazing cycle, pasture composition had a higher proportion of Italian ryegrass leaf blade (51.4\%), compared to oats (36.6\%), and herbivores preference for certain species of plants in a mixed canopy occurred primarily due to its relative availability (Carrère et al., 2001).

Due to the greater consumption of the Italian ryegrass by hoggets, at the end of the first pasture occupation, this grass had a lower residual leaf blade area and it was subjected to an environment with low light intensity due to upright growth habit of oats and to the rapid elongation of their internodes. Those conditions may have caused a decrease in competitive ability of Italian ryegrass, thus, in the second period of occupation, oats was the most abundant species (Table 1) and with greater disappearance in the mixture.

Evaluation periods did not affect the number of green and expanding leaves of Italian ryegrass ( $\mathrm{P}>0.1$; Table 2 ). Among the structural characteristics of ryegrass, only the number of expanding leaves was influenced by the evaluated grazing intensities, being greater in high intensity $(\mathrm{P}=0.028)$. For a canopy with a similar number of green leaves $(\mathrm{P}=0.41)$, the existence of a greater number of leaves in expansion may represent greater nutritional quality and greater photosynthetic efficiency (Parsons et al., 1983).

Grazing intensities did not influence any of the structural variables of black oats ( $\mathrm{P}>0.1$; Table 2$)$. Grass structural characteristics interfere on herbivore selectivity and also in the efficiency of forage harvesting (Stobbs, 1973), determining animal performance. Thus, it is suggested that recommendation for grazing intensity should be made according to Italian ryegrass structure in order to maintain a condition that optimizes the feeding behavior and intake of herbivores.

Grazing intensities did not affect oats phyllochron and its average value was equivalent to $137.36 \pm 3.66$ degreeday/leaf ( $P=0.69$ ). Quadros et al. (2003), when evaluating two leaf blade biomasses on oats plus ryegrass pasture, had observed a value $62.4 \%$ higher for oats phyllochron. Considering the average daily temperature of the first assessment period (Figure 1), it took 8.7 days for the appearance of one leaf of oats.
There is a positive correlation between phyllochron and sheath height of Italian ryegrass $(r=0.75 ; \mathrm{P}=0.03)$. Although the rate of leaf initiation in the apical meristem remains steady in relation to temperature, it takes a longer time for leaves to rise above the sheath as leaf sheath height increases (Duru \& Ducrocq, 2000).

There was an interaction between grazing intensity and evaluation period for phyllochron of Italian ryegrass $(\mathrm{P}=0.059)$. In the first grazing period, phyllochron did not differ among grazing intensities and its average value was $100.58 \pm 8.81$ degree-days. In the second grazing period, its value was $132.85 \pm 6.95$ and 108.39 degree-days for the low and high intensities, respectively $(\mathrm{P}=0.07)$. For a similar sheath height at both intensities (Table 2), the greater phyllochron at low grazing intensity may be related to shade imposed by leaves and other structures in the upper section of the canopy, inhibiting activity of buds and impairing the formation of new leaves (Frank \& Hofman, 1994).

The leaf rate emission of Italian ryegrass, in this experiment, was higher than that observed by Gonçalves \& Quadros (2003), who found value of 161.9 degree-days/leaf for ryegrass phyllochron in oats + Italian ryegrass + clover mixture under continuous stocking. This value was also higher than that observed by Cauduro et al. (2006), which was 276 degree-days/leaf of Italian ryegrass when managed under intermittent stocking.

It would be expected a higher tiller density of Italian ryegrass than those recorded by the authors above mentioned due either to a lower value of phyllochron or a direct relationship between leaf appearance and tiller density (Nabinger \& Pontes, 2001). However, the number of Italian ryegrass tillers was lower (Table 2) than the value reported by Cauduro et al. (2006) in an exclusive ryegrass pasture. This fact can be attributed to greater tiller mortality in Italian ryegrass associated to shading caused by the presence of oats in the mixture.

The duration of leaf elongation of oats and Italian ryegrass was not affected by grazing intensities $(\mathrm{P}>0.1)$ and their average values were $137.02 \pm 2.44$ and $178.09 \pm 8.39$ degree-days, respectively. The duration of elongation of Italian ryegrass was higher in the second period of evaluation (190.84 \pm 10.61 degree-days) than in the first (165.34 \pm 8.43 degree-days; $\mathrm{P}=0.05$ ).

There was neither grazing intensity $\times$ evaluation period interaction nor a grazing intensity effect on the rates of elongation and senescence of intact leaves of Italian ryegrass.

The senescence rate of intact leaves of Italian ryegrass, in intermittent grazing, was similar among evaluation periods (Figure 2). The senescence rate was, on average, 21.5\% 


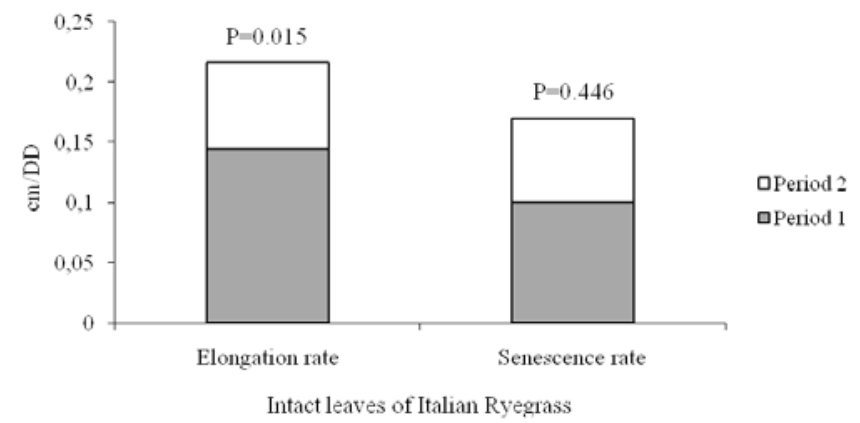

Figure 2 - Elongation and senescence rate of intact leaves of Italian ryegrass in evaluation periods for oats + ryegrass + red clover mixture.

lower than the elongation rate of tissues, indicating that the adopted interval between grazing cycles (less than the lifetime of leaves of ryegrass), probably allowed a positive balance among ryegrass fluxes of growth and senescence.

The lower rate of elongation of intact leaves in the second evaluation period is related to the Italian ryegrass phenological stage since, in this period, it began the floral differentiation and internodes elongation. At this moment, the photoassimilates are allocated primarily on the reproductive structures and with a decrease in leaf expansion rate (Skinner \& Nelson, 1995).

Elongation rate of intact leaves of Italian ryegrass was adjusted to the following multiple regression model $\left(\mathrm{R}^{2}=0.84\right)$ : ILER $=0.2335-0.0012$ duration of ryegrass elongation +0.0134 length of defoliated leaf blade (in $\mathrm{cm} /$ degree-day). The duration of elongation and defoliated leaf blade length determined were, respectively, $64.82 \%$ and $19.10 \%$ of the total variation on elongation rate of intact leaves of Italian ryegrass. For each 1 degree-day increase in duration of elongation, it is expected,in general, a reduction of intact leaves elongation rate of $0.0012 \mathrm{~cm} /$ degree-day. For every centimeter over the length of the defoliated leaf, it is expected an average increase of $0.0134 \mathrm{~cm} /$ degree-days in the elongation rate of intact leaves.

The influence of defoliated leaf blade length on the elongation of the intact leaf blade demonstrates the importance of residual leaf area in grass regrowth after grazing, once, in the first period, when the defoliated leaf blade length was longer, Italian ryegrass showed a leaf elongation also higher.

The defoliated leaf senescence rate of Italian ryegrass was positively correlated with the elongation rate of intact leaves $(\mathrm{r}=0.81, \mathrm{P}=0.014)$ and their values were higher in the first evaluation period. Thus, greater elongation rate of intact leaves of Italian ryegrass at the first evaluation period may also be related to a greater remobilization of nitrogen in tissue senescence (Nabinger \& Pontes, 2001).

There was an interaction between grazing intensity and evaluation period for defoliated leaf elongation rate $(\mathrm{P}=0.03)$, which in the first evaluation period, was greater in high grazing intensity $(0.154 \pm 0.021 \mathrm{~cm} /$ degree-days $)$ than in low grazing intensity $(0.066 \pm 0.021 \mathrm{~cm} /$ degreedays). In the second evaluation period, the defoliated leaf elongation rate did not differ among grazing intensities, with an average value of $0.042 \pm 0.004 \mathrm{~cm} /$ degree-day.

The highest values of elongation rate are observed at lower grazing intensities in Italian ryegrass pasture according to Pontes et al., 2003. However, a mixture of species makes the environment more complex because the response of plants to defoliation will depend on the defoliation degree in other mixture of species and it is influenced by the grazing selectivity by the animal (Cavalcante, 2001). Due to the higher consumption of ryegrass, the participation of oats in the mixture increased at the end of the first period of grazing (Table 1), and the high grazing intensity may have determined a reduction in light competition, resulting in increasing Italian ryegrass defoliated leaf elongation rate.

There was no influence of grazing intensities on the elongation rate of intact leaves neither on senescence rates of intact and defoliated leaves of black oats and their values were $0.139 \pm 0.032,0.11 \pm 0.029$ and $0.067 \pm 0.015 \mathrm{~cm} /$ degreedays, respectively $(\mathrm{P}>0.1)$.

The defoliated leaf elongation rate of oats differed among grazing intensities $(\mathrm{P}=0.002)$. At low grazing intensity, the average value was $0.081 \pm 0.022 \mathrm{~cm} /$ degreedays, while under high grazing intensity, it was $0.059 \pm$ $0.022 \mathrm{~cm} /$ degree-day. This difference between grazing intensities for oats defoliated leaf elongation rate did not modify pasture structure, since the intact and defoliated leaf blades lengths were similar among the tested grazing intensities ( $\mathrm{P}>0.1$ ). According to Marriot et al. (1999), factors such as leaf blade length, size of tiller and remobilization of nitrogen process, may help explain the increased rate of elongation under lower grazing intensities. However, in this experiment, the leaf blade length and size of tillers were not influenced by grazing intensity (Table 2).

There was no interaction between grazing intensity and period for leaf lifespan of Italian ryegrass. The leaf lifespan of the evaluated grasses did not differ among grazing intensities and their average values were $272.36 \pm 10.25$ degree-days and $342.88 \pm 28.51$ degree-days for oats and ryegrass, respectively. The leaf lifespan difference among species affects their ability to accumulate biomass and to reach the ceiling value of forage production on a pasture. 
The importance of the leaf lifespan is that it determines the proportion of total forage production that can actually be harvested in a program of grazing management (Lemaire \& Chapman, 1996).

Bandinelli (2004) observed that Italian ryegrass had reached its maximum growth rate before oats and both species presented higher values for leaf lifespan than those observed in this study, averaging 683 and 461.95 degree-days for oats and Italian ryegrass, respectively. In this experiment, although oats reached its maximal growth rate before ryegrass, it occurred relatively close for the two species. Thus, using 300 degree-days thermal time as an interval criterion between two cycles of grazing was efficient for oats + Italian ryegrass + red clover pasture management since it reduced oats senescence losses without, however, adversely affecting forage production of ryegrass.

\section{Conclusions}

In black oats + Italian ryegrass + red clover mixture, the removal of $61 \%$ of the initial forage mass at each grazing cycle does not alter structural characteristics of the oats. Thus, for intermittent grazing with 300 degree-day thermal sum interval among pasture occupation periods, the adoption of high intensity grazing management is suggested based on the favorable structure of ryegrass, expressed by the highest number of expanding leaves per tiller.

\section{References}

BANDINELLI, D.G. Morfogênese e produção animal em aveia (Avena strigosa Schreb.) e azevém (Lolium multiflorum Lam.) pastejados sob distintas biomassas de lâminas foliares. 2004. 156f. Dissertação (Mestrado em Zootecnia) Universidade Federal de Santa Maria, Santa Maria.

CARRÈRE, P.; LOUAULT, F.; SOUSSANA, J.F. Tissue turnover within grass-clover mixed swards grazed by sheep. Methodology for calculating growth, senescence and intake fluxes. Journal of Applied Ecology, v.34, p.333-348, 1997.

CARRÈRE, P.; LOUAULT, F.; CARVALHO, P.C.F. et al. How does the vertical and horizontal structure of a grass and clover sward influence grazing? Grass and Forage Science, v.56, n.2, p.118-130, 2001

CAUDURO, G.; CARVALHO, P.C.F.; BARBOSA, C.M.P. et al. Variáveis morfogênicas e estruturais de azevém anual (Lolium multiflorum Lam.) manejado sob diferentes intensidades e métodos de pastejo. Revista Brasileira de Zootecnia, v.35, n.4, p.1298-1307, 2006.

CAVALCANTE, M.A.B. [2001]. Compilação dos artigos: 1. Ecofisiologia de pastagens: aspectos da dinâmica das populações de plantas forrageiras em relvados pastejados (Lemaire, 2001) e 2. A fisiologia do crescimento de gramíneas sob pastejo: fluxo de tecidos (Lemaire, 1997). Disponível em: <http:www.forragicultura.com.br/> Acesso em: 10/10/2007.
COOPER, J.P.; TAINTON, N.M. Light and temperature requirements for the growth of tropical and temperate grasses. Herbage Abstracts, v.38, p.167-176, 1968.

DIFANTE, G.S. [2003]. Importância da morfogênese no manejo de gramíneas forrageiras. Disponível em: $<$ http:www.forragicultura.com.br/> Acesso em: 10/10/2007.

DURU, M.; DUCROCQ, H. Growth and senescence of the successive grass leaves on a tiller ontogenic development and effect of temperature. Annals of Botany, v.85, p.635-643, 2000.

EMPRESA BRASILEIRA DE PESQUISA E AGROPECUÁRIA EMBRAPA. Centro Nacional e Pesquisa em Solos. Sistema Brasileiro de Classificação de Solos. Brasília: EmbrapaSPI; Rio de Janeiro: Embrapa-Solos, 2006. 306p.

FRANK, A.B; HOFMAN, L. Light quality and stem numbers in cool-season forage grasses. Crop Science, v.34, n.2, p.468-473, 1994.

GLIENKE, C.; ROCHA, M.G.; ROSO, D. et al. Ingestive behavior and displacement patterns of beef heifers on Italian ryegrass pasture. Revista Brasileira de Zootecnia, v.39, n.2, p.247-254, 2010.

GONÇALVES, E.N.; QUADROS, F.L.F. Características morfogênicas de azevém (Lolium multiflorum Lam.) sob pastejo em sistemas intensivos de utilização. Ciência Rural, v.33, n.6, p.1129-1134, 2003.

HERINGER, I.; CARVALHO, P.C.F. Ajuste da carga animal em experimentos de pastejo: uma nova proposta. Ciência Rural, v.32, n.4, p.675-679, 2002.

INSTITUTO NACIONAL DE METEREOLOGIA. Divisão de Observação Metereológica. Curso de atualização para observador metereológico de superfície. Porto Alegre, 2004.

LANGER, R.H.M. How grasses grow. 2.ed. London: Edward Arnold, 1979. 66p.

LEMAIRE, G. Ecophysiology of grasslands: dynamics aspects of forage plant populations in grazed swards. In: INTERNATIONAL GRASSLAND CONGRESS, 19., São Pedro, 2001. Proceedings... São Pedro, 2001. p.29-37.

LEMAIRE, G.; CHAPMAN, C. Tissue flows in grazed plant communities. In: HODGSON, J.; ILliUS, A.W. (Eds.) The ecology and management of grazing systems. Guilford: CAB International, 1996. p.3-36.

MARRIOT, C.A.; BARTHRAM, G.T.; BOLTON, G.R. Seasonal dynamics of leaf extension and losses to senescence and herbivory in extensively managed sown ryegrass-white clover swards. Journal of Agricultural Science, v.132, p.77-89, 1999.

MAZZANTI, A.; LEMAIRE, G. Effect of nitrogen fertilization upon herbage production of tall fescue swards continuosly grazed by sheep. 2. Consumption and efficiency of herbage utilization. Grass and Forage Science, v.49, p.352-359, 1994

NABINGER, C.; PONTES, L.S. Morfogênese de plantas forrageiras e estrutura do pasto. In: REUNIÃO ANUAL DA SOCIEDADE BRASILEIRA DE ZOOTECNIA, 38., 2001, Piracicaba. Anais.. Piracicaba: FEALQ, 2001. p.755-771.

NUERNBERG, K.; DANNENBERGER, D.; NUERNBERG, G. et al Effect of a grass-based and a concentrate feeding system on meat quality characteristics and fatty acid composition of Longissimus muscle in different cattle breeds. Livestock Production Science, v.94, p.137-147, 2005.

PARSONS, A.J.; LEAFE, E.L.; COLLET, B. et al. The physiology of grass production under grazing. 1. Characteristics of leaf and canopy photosynthesis of continuously grazed swards. Journal of Applied Ecology, v.20, n.1, p.117-126, 1983.

PEDREIRA, G.S.P.; MELLO, A.C.L.; OTANI, L. O processo de produção em pastagens. In: REUNIÃO ANUAL DA SOCIEDADE BRASILEIRA DE ZOOTECNIA, 38., 2001, Piracicaba. Anais... Piracicaba: Fundação de Estudos Agrários Luiz de Queiroz, 2001. p.772-807.

PINTO, J.C.; GOMIDE, J.A.; MAESTRI, M. et al. Crescimento de folhas de gramíneas forrageiras tropicais, cultivadas em vasos, com duas doses de nitrogênio. Revista da Sociedade Brasileira de Zootecnia, v.23, n.3, p.327-332, 1994. 
PONTES, L.S.; NABINGER, C.; CARVALHO, P.C.F. et al. Variáveis morfogênicas e estruturais de azevém anual (Lolium multiflorum Lam) manejado em diferentes alturas. Revista Brasileira de Zootecnia, v.32, n.4, p.814-820, 2003.

PONTES, L.S.; CARVALHO, P.C.F.; NABINGER, C. et al. Fluxo de biomassa em pastagens de azevém anual (Lolium multiflorum Lam.) manejadas em diferentes alturas. Revista Brasileira de Zootecnia, v.33, n.3, p.529-537, 2004.

QUADROS, F.L.F.; BANDINELLI, D.G.; MARTINS, C.E.N. et al. Variáveis morfogênicas de aveia e azevém sob disponibilidades de lâminas foliares verdes e pastejo por bovinos. In: REUNIÃO ANUAL DA SOCIEDADE BRASILEIRA DE ZOOTECNIA, 40., 2003, Santa Maria. Anais... Santa Maria: Sociedade Brasileira de Zootecnia, [2003]. (CD-ROM).

QUADROS, F.L.F.; BANDINELLI, D.G. Efeitos da adubação nitrogenada e de sistemas de manejo sobre a morfogênese de Lolium multiflorum Lam. e Paspalum urviellei Steud. em ambiente de várzea. Revista Brasileira de Zootecnia, v.34, n.1, p.44-53, 2005.

QUADROS, F.L.F.; MARASCHIN, G.E. Desempenho animal em misturas de espécies forrageiras de estação fria. Pesquisa Agropecuária Brasileira, v.22, n.5, p.535-541, 1987.
ROCHA, M.G.; QUADROS, F.L.F.; GLINKE, C.L. et al. Avaliação de espécies forrageiras de inverno na Depressão Central do Rio Grande do Sul. Revista Brasileira de Zootecnia, v.36, n.6, p.1990-1999, 2007.

SARTO, F.M.; MIRANDA, S.H.G.; BRISOLARA, C.S. Análise dos impactos econômicos da implantação do sistema de identificação e certificação de origem bovina e bubalina no Brasil. In: CONGRESSO DA SOCIEDADE BRASILEIRA DE ECONOMIA E SOCIOLOGIA RURAL - SOBER, 41., 2003, Juiz de Fora. Anais.. Juiz de Fora: Sociedade Brasileira de Economia e Sociologia Rural, 2003.

STATISTICAL ANALYSIS SYSTEM - SAS. User's guide. Version 8.2. Cary: Statistical Analysis System Institute, 2001. 1686p.

SIMON, J.C.; LEMAIRE, G. Tillering and leaf area index in grasses in the vegetative phase. Grassland Forage Science, v.42, p.373-380, 1987.

SKINNER, R.H.; NELSON, C.J. Elongation of the grass leaf and its relationship to the phyllochron. Crop Science, v.35, p.4-10, 1995.

STOBBS, T.H. The effect of plant structure on the intake of tropical pastures. I. Variation in the bites size of the grazing cattle. Australian Journal of Agricultural Research, v.24, n.6, p.809-819, 1973. 